UDC: 811.111:81'27; 811.111'366.573'367; 070(410):81'27

\title{
THE USE OF THE PASSIVE IN THE BRITISH DAILY PRESS: A SOCIOLINGUISTIC APPROACH
}

\author{
MAJA KUJUNDŽIĆ \\ University of East Sarajevo, Faculty of Philosophy, \\ Department of English Language and Literature, \\ Bosnia and Herzegovina
}

Ovaj rad je inspirisan teorijom „,jezička upotreba uslovljena publikom" (eng. audience design) novozelandskog lingviste Alana Bela. Prema toj teoriji upotreba jezičkih sredstava ne zavisi od društvenog statusa govornika/ pisca nego od onih kojima je taj jezik upućen. U skladu sa ovim rad počiva na pretpostavci da ni upotreba određenih gramatičkih konstrukcija - u ovom slučaju upotreba pasivne konstrukcije u jeziku britanske dnevne štampe - neće biti proizvoljna nego će biti uslovljena socioekonomskim profilom čitalačke publike kojoj je taj jezik namenjen. S obzirom na to da se pasiv najčešće smatra odlikom formalnog jezičkog stila, u radu se pretpostavlja da će pasivna konstrukcija biti u najfrekventnijoj upotrebi u novinama čija čitalačka publika pripada najvišim socioekonomskim slojevima. Kako bi testirali ovu hipotezu, u radu je posmatrana frekventnost upotrebe pasivne konstrukcije u primjercima dnevne štampe koji su odabrani na osnovu socioekonomskog statusa njihove čitalačke publike: The Guardian (visokotržišne novine), Daily Mail (srednjetržišne novine) i The Sun (niskotržišne novine).

Ključne riječi: pasiv, frekventnost upotrebe, socioekonomski status, formalnost jezičkog stila, jezička varijacija, čitalačka publika.

This article is concerned with the use of the passive in the language of British newspapers. My initial hypothesis is that the use of this construction is correlated with the socio-economic status of the readers of the newspapers in question. The definition of the passive on which this article is based is taken from Quirk et al. (1985). They define the passive as a construction consisting of "an auxiliary (be or get) and a past participle" (Quirk et al. 1985: 167). On the basis of this very formal definition they posit the passive gradient in which passive-like constructions are divided into three classes: central (true) passives, semi-passives and pseudo passives. The prime criterion adopted for this classification is the potential of passive clauses to be transformed into

1 Kontakt podaci (Email): maja.vestida@gmail.com 
their direct active extensive counterparts. At the top of the gradient are central or true passives. They occupy this position since they can be placed in direct correspondence with their unique active counterparts and are therefore considered as 'ideal' passives. Mixed or semi-passives are found in the middle of the scale since they have both verbal and adjectival characteristics. The members of the third and final class only formally resemble the passive. They can neither have active counterparts nor agent extensions and are therefore called pseudo-passives.

All the passives found in my corpus are first divided into finite and non-finite constructions according to whether the verb element in a sentence is finite 'showing tense, mood, aspect and voice', or non-finite 'not showing tense or mood but still capable of indicating aspect and voice' (Quirk \& Greenbaum 1973: 17).

On the basis of Quirk et al's passive gradient, finite passives will be further divided into central, as in (1)-(4) semi-passives, as in (5)-(6) and pseudo-passives, as in (7)-(8), according to whether they have a clear correspondence with an active verb phrase or active clause. Non-finite passives are rarely dealt with in the literature. I therefore had to set up my own classification of such structures. In the present article they have been classified according to the function of the subordinate clause in which they occur: nominal, as in (9), adjectival, as in (10) and adverbial, as in (11). Examples (1)-(11) illustrate the constructions that will be dealt with in this article.

(1) The results of an inquiry by the Independent Police Complaints Commission into how Essex police investigated the suspicious death of Stuart Lubbock, 31, eight years ago were welcomed by the man's father, who said he was considering launching a civil case. (The Guardian, p. 7)

(2) The poll, which questioned 1,045 people, found that 63 per cent thought that the law should respect and be influenced by Britain's traditional religious values - in other words Christianity. (Daily Mail, p. 17)

(3) Nearly all women with breast cancer are denied the chance of reconstruction at the time they have a breast removed. (The Sun, p. 30)

(4) Though the regime is hardly undermined by sanctions, it is anxious to remain within the Nuclear Non-Proliferation Treaty, and has responded to pressure. (The Times, p. 2)

(5) The Met's defiance says that at the hearing that led to Saeed's dismissal the panel was concerned about the "demeanour" of one of his accusers. (The Guardian, p. 4)

(6) They were, deduced Mr Mackinley, 'ashamed and embarrassed by this announcement'. (Daily Mail, p. 4)

(7) AILING US insurance giant is poised to reveal losses of $£ 41$ billion - for a THREEMONTH period. (The Sun, p. 42)

(8) In her opening address to the conference, Mrs Lawrence said she feared that the issues of racial equality in many walks of public life had become "watered down". (The Guardian, p. 16)

(9) Many analysts had expected Thomson Reuters to be battered by the global recession, as banks cut their subscriptions to its real-time data services. (The Times, p. 47)

(10) A police officer told of his anger yesterday after being taken off frontline duty for a year and hauled before a court for defending himself against a suspect who he thought was about to headbutt him. (Daily Mail, p. 19) 
(11) Dr Martin Neovius, who led the Swedish study - published in the British Medical Journal - said: "The excess risk conferred by obesity in late adolescence was of similar magnitude as smoking ten cigarettes a day." (The Sun, p. 17)

As previously indicated this article observes the use of the passive in a certain context and therefore deals with more than just its syntactic properties. Namely, its main objective is to account for the frequency and use of the passive in British daily press. Questions concerning context, frequency and rationale behind the use of a particular linguistic structure inevitably lead us to the concept of style. According to Jucker (1992) there are three specific approaches to the concept of style within the confines of linguistics i.e. the concept of style as used by traditional stylistics, the ethnography of speaking, and correlational sociolinguistics. Since this article correlates certain linguistic features with a non-linguistic feature such as the socioeconomic status of newspapers' readers, it is obvious that this article is closely connected to the concept of style as approached by correlational sociolinguistics. Jucker then continues with his discussion of variety and style in light of the failure of traditional approaches to style to distinguish between style and other varieties, even though they take into consideration the context and situation of production of the text. In his discussion Jucker talks about "interspeaker and "intraspeaker" variation. Interspeaker variation refers to variation "according to the users" (Jucker 1992: 23) and in this sense the connection of interspeaker variation with the notion of style in correlational sociolinguistics is obvious. That said, however, variation can be dictated by both users and audience. Jucker defines "intraspeaker" variation as "a correlate of the speaker's audience" (Jucker 1992: 25). Furthermore, intraspeaker variation is correlated with the "audience design" as defined by Bell (1977), who investigated the style of speakers on New Zealand radio stations. He noticed that sometimes the style of the same speaker would differ according to radio station. Since this change could not be attributed to the difference in the speaker's age, social status, occupation or the style of broadcast (reading style), he concluded that there must be a correlation between this kind of variation and the audience: "The intraspeaker variation is explained in terms of the social status, sex and age not of the speaker but of the hearers" (Jucker 1992: 28). Jucker applies Bell's audience design to the classification of the newspapers he uses in his study of noun phrase complexity in different newspapers. Accordingly, he dismisses the traditional classification of British newspapers into "qualities" and "populars" as unsuitable since each designation refers to two different concepts. The term 'quality' implies a judgement on the value of newspaper while 'popular' refers to the audience. He also dismisses the classification that divides newspapers according to their format into "broadsheets" and "tabloids". This classification, like the traditional one, fails to take account of the fact that "the tabloid newspapers, which are traditionally regarded as popular, fall into two quite distinct groups, if, among other things, the readership appeal of the papers is taken into consideration." (Jucker 1992: 48).

Finally, Jucker adopts the terms introduced by Henry (1983) and divides all the newspapers into upmarket, midmarket and downmarket, according to the socioeconomic profile of their readers. Like Jucker we will also use Henry's classification of newspapers in this article. The results periodically published by the Joint Industry 
Committee for National Readership Surveys based on the occupation on the head of the household show that the majority of readers of upmarket newspapers belong to the middle class and the upper middle class, the majority of the readers of midmarket papers are members of the lower middle class and the skilled working class while a great number of the readers of downmarket papers are members of the skilled working class, the working class and those at the lowest level of subsistence. On the basis of this classification the newspapers analysed in this article belong to the following newspaper categories: The Guardian (upmarket), Daily Mail (midmarket) and The Sun (downmarket)

All three newspapers were published on February 29, 2009. The same number of words $(33,066)$ from each newspaper was investigated, the corpus thus totalling 99,198 words. The frequency of the passives will also be given per 1,000 words as well as their percentage in the total number of the investigated words. The investigated words include orthographic words, i.e. 'any set of letters or numbers enclosed by spaces or punctuation' (Biber et al. 1999: 38). Hyphenated words are counted as single words. The corpus is drawn only from news articles. Letters to the editors, comments and advertisements are excluded from the investigation, as are headlines.

Inspired by Allan Bell's theory of "audience design" my article is based on the hypothesis that the frequency of passive use will not be random, but closely related to the socio-economic profile of the readers of the analysed newspapers. Since the passive is "more frequent in formal than in informal styles" (Trudgill 2002: 162), the main hypothesis of my article is that it will be used more frequently in those newspapers whose readers belong to higher socio-economic classes. Namely, the vast majority of readers who belong to higher socio-economic classes are also the most educated members of society. Given their education, they have frequently been exposed to standard and formal varieties of the language, which has in turn largely influenced their own linguistic preferences and use. In accordance with this I have presumed that, in their choice of daily press, such readers will choose those newspapers which are characterized by the use of more standard and formal language. On the basis of this I have hypothesized that the language employed in The Guardian will be more formal than the language in the Daily Mail, while the language used in The Sun will be characterized by the lowest level of formality. Accordingly, the passive construction, being characteristic of formal language, will be most frequently used in The Guardian, somewhat less frequently in the Daily Mail, and least frequently in The Sun.

The tables below show the results of my investigation, which will be tested against my hypothesis.

\begin{tabular}{|l|l|l|l|}
\hline \multicolumn{5}{|l|}{ All passives } & Freq. & 1000 & $\%$ \\
\hline & 471 & 18 & 39.9 \\
\hline The Gurdian & 390 & 14.9 & 33.1 \\
\hline Daily Mail & 318 & 12.1 & 27 \\
\hline The Sun & 1179 & 15.2 & 100 \\
\hline Total & & \\
\hline
\end{tabular}

Table 1: All passives - frequency 
As shown in table 1, passives are most frequently used in The Guardian with 471 (39.9\%) occurrences, less frequently in the Daily Mail with 390 (33.1\%) occurrences, while they are least frequently used in The Sun with 318 (27\%) appearances. As noted, the passive is regarded as the characteristic of formal language. This is consistent with the fact that the majority of The Guardian readers belong to 'well-educated socioeconomic classes' (Jucker 1992: 53) while, in comparison, the majority of Daily Mail readers belong to less affluent and educated socio-economic classes, and therefore the language in this newspaper is less formal than the language used in The Guardian. In this respect it comes as little surprise that the language used in The Sun is least formal since the majority of its readers belong to the least affluent and educated socioeconomic classes. Such results agree with my hypothesis according to which language use is strongly correlated with the socio-economic profile of the audience.

\begin{tabular}{|c|c|c|c|c|c|c|c|}
\hline \multicolumn{8}{|l|}{ All passives } \\
\hline & \multicolumn{3}{|l|}{ Finite } & \multicolumn{3}{|c|}{ Non-finite } & \\
\hline & Freq. & 1000 & $\%$ & Freq. & 1000 & $\%$ & Total Freq. \\
\hline The Guardian & 334 & 12.7 & 38.9 & 137 & 5.2 & 45.4 & 471 \\
\hline Daily Mail & 289 & 11 & 33.6 & 101 & 3.9 & 33.4 & 390 \\
\hline The Sun & 236 & 9 & 27.5 & 82 & 3.1 & 27.2 & 318 \\
\hline Total & 859 & 10.9 & 100 & 302 & 3.8 & 100 & 1179 \\
\hline
\end{tabular}

Table 2: All passives - finiteness

Table 2 shows that in terms of total numbers of passives found in all three newspapers, finite passives are more frequent than non-finite passives. There are 859 occurrences of finites and 302 occurrences of non-finites, making a total of 1,179 passives. Contrary to non-finite passives, verbs in finite passives, as their name implies, appear in finite form, give us information about person and tense, and in this way are more informative and explicit than verbs in non-finite passives. Based on this we can conclude that the language of newsapers (one of the most popular media) generally strives to be both highly informative and explicit.

As shown in Table 1, both finite and non-finite passives are most frequent in The Guardian, least frequent in The Sun, with the Daily Mail again occupying the mid position - expressed in terms of numbers: 334 vs. 289 vs. 236 for finites, and 137 vs. 101 vs. 82 for non-finites. The ratios are thus quite similar for all three newspapers: $38.9 \%$ vs. $33.6 \%$ vs. $27.5 \%$ for finites, and $45.4 \%$ vs. $33.4 \%$ vs. $27.2 \%$ for non-finites. These results correspond to Biber et al. (1999) and their corpus-based findings which show that nonfinites are generally less frequent than finites. The frequency of finite passive use in the newspapers analysed further supports my hypothesis.

Even though non-finite passives are less explicit and informative than finite passives they still represent a form of a passive construciton, which is generally considered to be formal in its expression. That explains the fact that the freqency of their use is again highest in those newspapers whose readers belong to the most affluent socioeconomic classes, and therefore they tend towards the use of more formal and standard 
varieties of language in their articles. In this regard, their freqeuncy is also strongly correlated with the socio-economic profile of a newspaper's readers.

\begin{tabular}{|c|c|c|c|c|c|c|c|c|c|c|}
\hline \multicolumn{11}{|l|}{ Finite passives } \\
\hline & \multicolumn{3}{|c|}{ Central } & \multicolumn{3}{|l|}{ Semi } & \multicolumn{3}{|c|}{ Pseudo } & \multirow[b]{2}{*}{ Sum } \\
\hline & Freq. & 1000 & $\%$ & Freq. & 1000 & $\%$ & Freq. & 1000 & $\%$ & \\
\hline The Guardian & 307 & 11.7 & 41.4 & 14 & 0.5 & 20 & 10 & 0.4 & 20.8 & 334 \\
\hline Daily Mail & 243 & 9.3 & 32.8 & 23 & 0.9 & 32.9 & 17 & 0.6 & 35.4 & 289 \\
\hline The Sun & 191 & 7.3 & 25.8 & 33 & 1.3 & 47.1 & 21 & 0.8 & 43.8 & 236 \\
\hline Total & 741 & 9.4 & 100 & 70 & 0.9 & 100 & 48 & 0.6 & 100 & 859 \\
\hline
\end{tabular}

Table 3: Finite passives - possibility of having active counterparts

According to Table 3, central passives are more frequent than semi- and pseudopassives in all three newspapers. Central passives are again most frequently used in The Guardian (307 occurrences, 41.4\%), less frequent in the Daily Mail (243, 32.8\%), while The Sun again brings up the rear with the smallest numbers of passives $(191,25.8 \%)$ found in the same number of words. Semi-passives are more frequent than pseudopassives in all three nespapers. As to semi-passives, 14 (20\%) instances of this passive category appear in The Guardian, 23 (32.9\%) in the Daily Mail, and 33 (47.1\%) in The Sun. Pseudo-passives represent the least frequent category, with 10 (20.8\%) instances in The Guardian, 17 (35.4\%) in the Daily Mail, and 21 (43.8\%) in The Sun. It is interesting to note that when it comes to the frequency of both semi- and pseudo passives, the results are unlike those that have appeared in the previous tables. Namely, the frequency of their use goes the other way around, thus they are most frequent in The Sun, less frequent in the Daily Mail, while the number of their occurrences is the smallest in The Guardian. It would appear that semi- and pseudo passives differ from central passives in that they lack the 'formaility' of the latter category. Given that The Sun is characterized by the use of the least formal language of the three analysed newspapers, it is not surprising that the frequency of semi- and pseudo-passives in that newspaper is higher than in the Daily Mail, which is characterized by the use of more formal language, while they are least frequent in The Guardian, which employs the most formal language in its texts.

\begin{tabular}{|c|c|c|c|c|c|c|c|c|c|c|}
\hline \multicolumn{11}{|c|}{ Non-finite passives } \\
\hline & \multicolumn{3}{|c|}{ Nominal } & \multicolumn{3}{|c|}{ Adverbial } & \multicolumn{3}{|c|}{ Adjectival } & \multirow[t]{2}{*}{ Sum } \\
\hline & Freq. & 1000 & $\%$ & Freq. & 1000 & $\%$ & Freq. & 1000 & $\%$ & \\
\hline The Guardian & 12 & 0.5 & 36.4 & 32 & 1.2 & 42.1 & 92 & 3.5 & 43.8 & 137 \\
\hline Daily Mail & 11 & 0.4 & 33.3 & 23 & 0.9 & 30.3 & 68 & 2.6 & 32.4 & 101 \\
\hline The Sun & 10 & 0.4 & 30.3 & 21 & 0.8 & 27.6 & 50 & 1.9 & 23.8 & 82 \\
\hline Total & 33 & 0.4 & 100 & 76 & 0.9 & 100 & 210 & 2.6 & 100 & 320 \\
\hline
\end{tabular}

Table 4: Non-finite passives - function 
Table 4 shows that the frequency of adjectival non-finite passives (210 occurrences) is considerably higher than the frequency of adverbial (37 occurrences) and nominal non-finite (33 occurrences) passives in all three analysed newspapers. In all three newspapers, adjectival non-finite passives are also followed by adverbial and nominal non-finite passives: The Guardian (92 vs. 32. vs 12), the Daily Mail (68 vs. 23 vs. 11), and The Sun ( 50 vs. 21 vs. 10).

The high frequency of adjectival non-finite passives could be partly explained by Jucker's (1992) findings concerning syntactic variation within the noun phrase across different styles of English newspapers. Jucker's data show that the adjectival non-finite passive assumes the role of postmodifier in a noun phrase. Jucker (1992: 104) states that postmodifiers are more explicit than premodifiers. Therefore it is not surprising that adjectival non-finite passives as noun postmodifiers are frequently used in all three newspapers since they in general aim at using explicit language. The fact that noun postmodifications are most frequently used in The Guardian, less frequently in the Daily Mail and least freqently in The Sun is probably an indication that the language of The Guardian is most specific and explict, it is less such in the Daily Mail, while it is least specific and explicit in The Sun. As noted above, being explicit and specific are characteristics of more formal language use, therefore we can conclude again that the language used in The Guardian is more formal than the language used in the Daily Mail, while it is least formal in The Sun, which confirms our hypothesis according to which the level of language formality will be proportional to the socio-economic profile of newspapers' readers.

On the basis of the findings mentioned above it seems legitimate to conclude that the present investigation has confirmed my initial hypothesis that the passive is most frequently used in The Guardian, less frequently used in the Daily Mail, while the frequency of its use is lowest in The Sun. As far as my data go, they show that the language of The Guardian tends to be more formal than the language of the Daily Mail whose language is more formal than the language of The Sun. My data therefore support the claims made by scholars such as Bell (1984) and Jucker (1992), according to whom the use of linguistic features is not random, but to a great degree dictated by certain non-linguistic features, such as the socio-economic profile of readers.

\section{REFERENCES}

Bell, A. 1977. The language of radio news in Auckland: a sicoilinguistic study of style, audience and subediting variation. University of Auckland. Unpublished Ph.D. dissertation.

Bell, A. 1984. Language style as audience design. Language in Society 13, 145-204.

Biber et al. 1999. Longman Grammar of Spoken and Written English. London: Longman.

Henry, H. (ed.). 1983. Readership Research: Montreal 1983 Proceedings of the Second International Symposium. Amsterdam: Elsevier Science Publishers.

Jucker, A. 1992. Social Stylistics. Syntactic Variation in British Newspapers. Berlin/New York: Mouton de Gruyter.

Quirk, R. \& S. Greenbaum. 1973. A University Grammar of English. London: Longman. 
Quirk, R.etal.1985. A Comprehensive Grammar of The English Language. London: Longman. Trudgill, P. 2002. Socilinguistics, Variation and Change. Edinburgh: Edinburgh Univeristy Press.

\section{SUMMARY}

\section{THE USE OF THE PASSIVE IN THE BRITISH DAILY PRESS: A SOCIOLINGUISTIC APPROACH}

This paper is inspired by the theory of "audience design" (Bell 1977) according to which language variation is not based on the socio-economic status of language users, but on the socio-economic status of those at whom language is directed, i.e. receivers, or intended audience. In this regard, the author of this article assumes that language use, or more to the point, the use of certain syntactic structures such as the passive, will differ in newspapers whose readers belong to different socio-economic classes. Since the passive is usually seen as being "more frequent in formal than in informal styles" (Trudgill 2002: 162), it is presumed that it will be used more frequently in those newspapers whose readers belong to higher socio-economic classes. The analysed articles are therefore taken from a representative cross section of newspapers, divided on the basis of the socio-economic status of their readers into upmarket (The Guardian), midmarket (the Daily Mail), and downmarket newspapers (The Sun). The method used is quantitative-qualitative.

KEYWORDS: the passive, frequency, socio-economic status, newspapers, language variation, readership.

(Original scientific paper received 26.12.2012;

revised 31.10.2012; accepted 28.11.2012) 